\title{
Haaga-Helia
}

ammattikorkeakoulu

HUOM! Tämä on alkuperäisen artikkelin rinnakkaistallenne. Rinnakkaistallenne saattaa erota alkuperäisestä sivutukseltaan ja painoasultaan.

Käytä viittauksessa alkuperäistä lähdettä:

Harmaala, Minna-Maari (2015). The Sharing city as a platform for a more sustainable city environment? International Journal of Environment and Health, 7(4).

PLEASE NOTE! This in an electronic self-archived version of the original article. This reprint may differ from the original in pagination and typographic detail.

Please cite the original version:

Harmaala, Minna-Maari (2015). The Sharing city as a platform for a more sustainable city environment? International Journal of Environment and Health, 7(4).

The final publication is available at: https://doi.org/10.1504/IJENVH.2015.077116

DOI: 10.1504/IJENVH.2015.077116 
Author:

Minna-Maari Harmaala

Principal Lecturer

Ph.D.

Tel. +358 505475947

@MinttuHarmaala

Haaga-Helia University of Applied Sciences

Ratapihantie 13

FI-00520, Helsinki

www.haaga-helia.fi

Ph.D. Minna-Maari Harmaala works as principal lecturer of Corporate Responsibility at HAAGA-HELIA University of Applied Sciences. She has over ten years of practical industry experience from consulting in sustainability management, especially in the electronics sector. She has worked with a number of multinational clients prior to joining HAAGA-HELIA and is currently active in public-private partnerships at the University. She holds a Ph.D. from the University of Jyväskylä. Her dissertation looked at the industry wide sustainability effects of technology investments and was approved in 2001. Dr. Harmaala is an author of a textbook in Finnish on corporate responsibility and of various articles in scientific journals. She has robust international experience both from living and working abroad. Her areas of interest and expertise are the sharing economy, corporate responsibility, sustainability marketing and communication, strategic CSR and environmental management. 


\section{The Sharing city as a platform for a more sustainable city environment?}

The collaborative economy represents a new way of thinking about business, exchange, value and community. Activities and models within the collaborative economy enable access instead of ownership, encourage decentralized networks over centralized institutions, and provide new models to unlock wealth and often do so to a wider group of stakeholders. They make use of idle assets and create new marketplaces.

It seems there are numerous environmental savings and resource utilization benefits that follow from widespread adoption of collaborative models. Moreover, there may be a flow of social benefits that come from engagement and the enhancement of community spirit and belongingness. This paper will explore the concept of the collaborative economy and sharing cities as well as questions related to what cities stand to gain through the adoption of sharing initiatives, how a city can start promoting collaborative lifestyles and be used as platforms for sharing.

Key words: collaborative economy, meaning, resource efficiency, competitive advantage, engagement, sharing cities, disruption, sustainability

\section{Introduction}

The collaborative economy is impossible to ignore; it is undeniably a global movement, the next big trend in social commerce, and represents a potential $\$ 110$ billion market (Contreras 2011). The collaborative economy represents a new way of thinking about business, exchange, value and community. While its definitions are varied and parameters continue to evolve, activities and models within the collaborative economy enable access instead of ownership, encourage decentralized networks over centralized institutions, provide new models to unlock wealth and often do so to a wider group of stakeholders. They make use of idle assets and create new marketplaces. Van den Hoff (2013) amongst others, sees that this will lead to a situation and society where the traditional ways of doing business, existing rules and the current regulatory framework are challenged and questioned and to a vision of the society of the future dominated by new economic and social models. Hoff's Society 3.0 is a model that embraces new models of consumerism, sharing, participation and democratic decision-making.

The burgeoning peer-to peer economy has also disrupted traditional business models (for example Eckhardt \& Bardhi 2015) and upset the regulatory status quo. The sharing economy is extending to new and different types of markets and as such provides plenty of opportunities for entrepreneurial activity across different industries and fields. At this rate, peer-to-peer sharing is transforming from an income boost through a stagnant wage market, into a disruptive economic force. In the new realm, companies can explore how to provide value by enabling peer-to-peer sharing or company-enabled platforms for sharing. First-mover companies can benefit from the collaborative economy trend instead of seeing it as a threat to their existing business. Existing enterprises have clear assets, such as established brands, channels and financial muscles with which they can become the leaders in the collaborative economy. 
The peer-to-peer market is surpassing any other markets in outlook and market growth. Recent estimates by Forbes place the sharing economy at 3,5 billion USD in 2013 with a market growth rate of over $25 \%$ (Forbes 2013, Dervojeda et al. 2013). PwC estimated in 2014 the five key sectors of the sharing economy globally to be around USD 15 billion and expected to grow to USD 335 billion by 2025 (PwC 2014). AirBnb, perhaps one of the most raved examples of the collaborative economy, sees over 12 million annual guests staying in 34,000 cities globally (Riley 2014). In mid-2014 Airbnb reached 15 million served customers and is serving roughly one million guests monthly (Abhishek 2014). To be sure, those figures still pale next to the entire U.S. hotel industry, which according to research firm STR sold 1 billion nights alone between January and November 2012. But if you add Airbnb's 600,000 listings to the equivalent type of places available on vacation-oriented sites like HomeAway, suddenly house-sharing is larger in terms of room count than all the Hilton-branded hotels in the world. Airbnb is forecasted to grow to 100 million nights per year, a figure that would likely produce revenue of more than $\$ 1$ billion, up from an estimated 150 USD million in 2012 and 250 million USD in 2013. Some estimates assume that Airbnb's revenues will cross the half billion mark at roughly USD 675 million in 2015 (up from USD 423 million in 2014) demonstrating a whopping jump over the previous years (Ali 2015).

Airbnb raised capital in 2014 with a \$10 billion valuation (Wall Street Journal 2014, Weber 2014), meaning it was valued at more than some of the hotel chains it is increasingly competing against. More current valuation estimates place the valuation already at double this, USD 20 billion (Ali 2015). Wyndham, with 7,500 hotels under brands like Ramada, had $\$ 5$ billion in revenue and is valued at $\$ 9.4$ billion. Hyatt Hotels, with more than $\$ 4$ billion in revenue, is worth $\$ 8.4$ billion. (Wall Street Journal 2014). The figures alone clearly demonstrate that business models built on the idea of the collaborative economy have not only huge growth potential but also a huge disruptive potential.

Some promising start-ups in the sharing economy have already changed ownership, for example Avis acquiring Zipcar with a substantial price-tag of 500 million USD (Kell 2013) or Daimler consolidating Car2Go (Mattioli \& Boston 2014). Although these are only examples, they demonstrate the immense potential for the collaborative economy to disrupt traditional industries and force the companies in those industries to rethink their business logic. Not only are collaborative business models posing a threat and opportunity for traditional businesses, they are also posing an interesting new challenge and opportunity for cities to rethink their organization, governance, decision-making and services.

\section{Capitalism in crisis paving the way for sharing and collaboration}

Capitalism has inherent contradictions and crises are part of its operating system. Some of these crises are long lasting, some are short, but in all cases they are part of its development. Contextual conditions of each period of time lead to different ways out of each crisis, which sometimes means merely escaping rather than creating long lasting real change (for example Onaran, 2010, da Silva et. al. 2014). Capitalism has been largely criticized for recent financial, social and environmental crises. (Porter \& Kramer 2011, Heinrichs 2013, Eisenstein 2011, etc.). Due to the global nature of the current economic system, the effects of any crises or hiccup will spread throughout the globe at a very accelerated pace, despite being initiated in even a relatively small and contained region. (Foster \& Magdoff 2011). 
The current global market of consumer goods, services and financial products emphasizes the interconnectedness of geographical regions. As a result, stagnating economic growth in the so-called developed countries has resulted in flattening economic growth in other regions as well (Foster \& Magdoff 2011, Vandepitte 2011).

Porter and Kramer (2011) argue that despite its shortcomings, capitalism is an unparalleled vehicle for meeting human needs, improving efficiency, creating jobs, and building wealth. But a narrow conception of capitalism has prevented business from harnessing its full potential to meet society's broader challenges. The opportunities have been there all along but have been overlooked. This same argument has been expressed by numerous others as well, including Sempels and Hoffman (2013) who argue that sustainable innovation and new business models can be fantastic drivers of both value creation and orientation towards sustainable growth and a more desirable future.

During the global financial and economic crisis of the past five years, alternative perspectives on capitalism and consumerism have been voiced. Between the poles of "repairing" and improving regulation of the existing "system" and radical alternatives to a capitalist market society, a third perspective has gained attention. The concept and practice of a "sharing economy" and "collaborative consumption" suggest making use of market intelligence to foster a more collaborative and sustainable society. Heinrichs (2013) strongly believes that the sharing economy is a global phenomenon with remarkable dynamics, not just hype.

At the same time, alternative approaches rise. Jeremy Rifkin (2014) argues that during the past 10 years, the growth of the NGO sector in the US has doubled economic growth and NGOs are currently employing over $10 \%$ of the work force in US, UK and Canada. Instead of for-profit value creation, a more collaborative mindset is emerging. His argument states that social capital is as important as financial capital, access trumps ownership, sustainability supersedes consumerism, cooperation ousts competition, and "exchange value" in the capitalist marketplace is increasingly replaced by "sharable value" on the Collaborative Commons. Capitalism will stay with us but in a different more streamlined mode.

The past three decades have witnessed an erosion of the categorical divide between profit-based and nonprofit enterprise, as various types of businesses have emerged that embody characteristics of both. Businesses have traditionally been categorized by ownership and predominant profit objectives (Fottler 1981). A typical classification is between private and public ownership and commercial and social purpose (Grassl 2011). Such classification divides economic activity neatly into two sectors and assumes two objectives of business. Grassl (2011) among others argues that there is an idle operating space for hybrid organizations between the current non-profit and the for-profit dichotomy as also suggested by the notions of shared value (Porter \& Kramer), Base of the pyramid businesses (Prahalad), the B-Corps movement; and in fact many examples of the collaborative or sharing economy.

\section{What is the collaborative economy?}

Currently, there's a lot of emerging discussion in regards to collaborative commons. Some of the key premises of the capitalism model have been questioned after the financial crises of 2008. We're looking at a situation where the trust on companies' capabilities to provide value and create jobs is declining and 
economic growth as whole is slowing down. These issues are based on multiple simultaneously concurrent events: marginal prices of products are rapidly declining, market saturation is increasingly high, many of the basic needs of consumers are or are to be fulfilled, and, the creation of value is no longer connected with job creation.

The collaborative economy builds on distributed networks of connected individuals and communities. The rise of new forms of consumption is not constrained to individual actions of buying goods to satisfy needs, but includes collaborative consumption, focusing on: products as services; redistribution markets; and collaborative life-styles (Botsman \& Rogers, 2010). Solutions for the shared use of goods exist in the private (C2C/P2P), public (public sector-to-consumer) and the commercial (B2C) spheres. The current growth of the collaborative economy is due to the emergence of new urban lifestyles, and more importantly, the development of digital platforms that enable new forms of collaboration, as well as the development of professional skills and services that allow the replication of individual collaborative solutions. Proponents argue that it is based on peer-to-peer sharing of resources; however, this sharing is often facilitated by commercial companies. Their business logic is different from companies that earn from product sales, but they often collaborate with such companies and offer value to them.

Currently a vast mix of terms is used in connection with the collaborative economy. Often synonymously used are collaborative consumption, the sharing economy and the peer-to-peer economy. Botsman (2013) emphasizes the need to distinguish between these and provides distinctions for the terms. The collaborative economy is built on networks of connected individuals and communities instead of centralized organizations and transforms how we produce, consume, finance and learn. Collaborative consumption is an economic model based on sharing, swapping, trading or renting providing access over ownership. The sharing economy is an economic model based on sharing underutilized assets whereas the peer economy includes marketplaces that facilitate the sharing and trade of products and services built on peer trust.

Examples of collaborative commons are, eg. the sharing economy, peer production and co-creation. Key differences in these new models of behavior are within the cost structure and co-operation models. Instead of ownership, key concept is access. Instead of profit margins, key behavior is in sharing.

Collaborative commons already work as an alternative for the old value creation model. New practices and emerging lifestyles that connect with collaborative commons are already to be seen. New models of collaborative value creation take into account, eg. social enterprises and local communities. These new emerging practices appear to be in a position to provide complimentary approaches for value creation in the future. Prime examples are time and skill banks, sharing economy services and local co-creation of housing.

Owyang (2014) has split the collaborative economy into twelve distinct areas or spheres in his visual work in the following picture. Collaborative consumption currently includes prominently such areas as transportation, food, services, goods, money and space. The newer additions to the sphere are utilities (especially telecommunications and energy), health \& wellness, learning, corporate (including employee services and private labels), municipal (such as equipment and safety) and logistics. He identifies the key forces shaping the development to be either societal, such as the desire to connect or the sustainability mindset, economic such as the financial climate or technology enablers such as the internet and mobile technologies. Botsman (2014) on the other hand sees the collaborative economy to be thriving based on five key problems of redundancy, broken trust, limited access, waste and complexity. 


\section{Collaborative Economy Honeycomb Version 2.0}

The Collaborative Economy enables people to get what they need from their community. Similarly, in nature, honeycombs are resilient structures that enable many individuals to access. share, and grow resources among a common group.

In the original Honeycomb graphic. six distinct families of startup types were represented by the inner track of hexes. In a very short period of time. this movement has expanded, as reflected in the six additional hexes on the outer perimeter.

This visual representation of the movement is organized into families. classes. and startup examples. To access a complete directory of over 9,000 startups worldwide, advance to the Mesh Directory. managed by Mesh Labs: http://meshing.it/

\section{By Jeremiah Owyang}

jeremiah@CrowdCompanies.com

@jowyang. Dec 2014

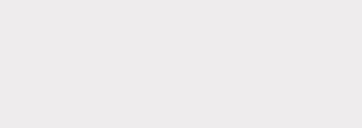
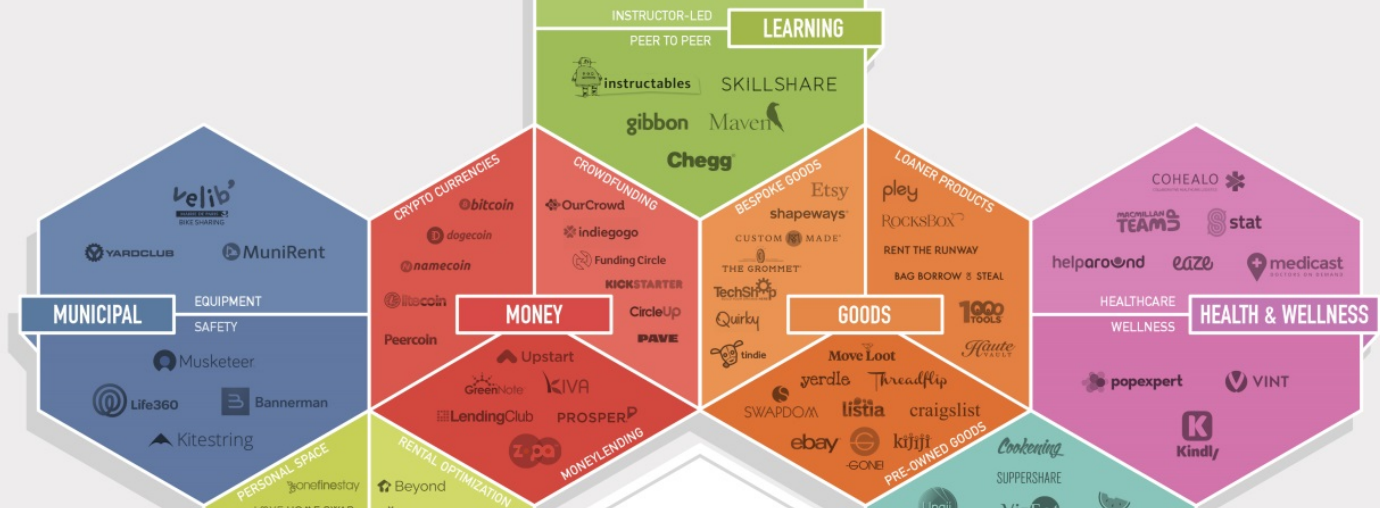

popexpert VINT

K

EMPOWERED PEOPLE
MAKRSS CO-CREATRS.

PEERS. CUSTOMERS

Nivin
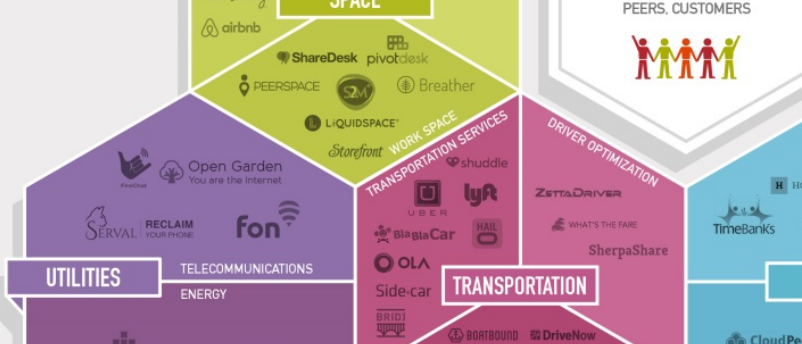

Y

Button

Rear Mle

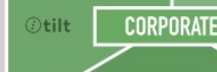

The sharing economy is characterized by an explosion of practices such as carsharing, ridesharing, cooperatives, community farms, shared housing, shared workspaces, and a multitude of new microenterprises made possible by platforms that connect supply and demand at the peer-to-peer level. 
Examples of prominent companies operating in the sharing economy are Airbnb, Lyft, Sidecar, TaskRabbit and Uber.

There are only few studies of how much people are using the collaborative economy. In Germany research reveals that more than 50 percent of consumers have experience with some form of sharing economy, and that approximately 25 percent can be described as "socio-innovative co-consumers" (Heinrichs and Grunenberg 2013). Another study by VisionCritical demonstrates that $40 \%$ of the adult population in the US and $52 \%$ in the UK have used sharing economy enabled platforms to access goods, services, transportation, money or space from other consumers instead of going through traditional means (Owyang et. al. 2014). A supply-side focus suggests there has also been a dynamic increase in sharing models concerning cars, bikes, rooms, food, gadgets, etc.. Similar observations can be made for product service systems within business and between businesses and consumers or redistribution markets, including upcycling and other ways of finding new uses for old things.

\section{Digitalization as a mediator}

The internet makes it cheaper and easier than ever to aggregate supply and demand. Smartphones with maps and satellite positioning can find a nearby room to rent or a car to borrow. Online social networks and recommendation systems help establish trust. Internet payment systems can handle the billing. People are looking to buy services directly when they need them, instead of owning an asset. Providing a secure platform for financial transactions is vital, but creating a trusting community is just as important when it comes to attracting users. Social media has reshaped both the nature of marketing communications as well as consumer behavior by completely changing the way in which consumers interact with brands and with each other (Berthon et. al. 2008).

Friedman (2005) and van den Hoff (2013) affirm that competition and collaboration at a global scale, among individuals and companies, are now cheaper, easier, less conflictive, more productive, and reaching an ever increasing number of people. Global society lives in an era where technology will literally transform the business world, life, and society in all aspects (Friedman 2005, Benkler 2006, Rifkin 2014). According to Friedman (2005), in the 2000's a global playing field was created and, articulated through the web, made different forms of collaboration viable, meaning the sharing of knowledge and work at global scale. According to Belk (2007), sharing here can be understood as the act or process of distribution of what is ours for others to use, and/or the act or process of receiving/taking something that belongs to others for our own use. There are several on-line communities flourishing, and a trend towards collective production and innovation (Kozinets et al., 2008).

The advancement and dissemination of ICTs made possible new forms of sharing, and the ascension of platforms for collective practices that allow interaction, free access to information, knowledge exchange, creation and collaboration. In an organizational environment, these practices indicate new business models, new ways of conducting decision making processes, product development and collective learning for example. It can be said that innovation in several leading companies are increasingly a result of horizontal collaboration, among different departments and teams spread all over the globe (Friedman, 2005). Many companies started seeing their employees as a great conglomerate of individual specialists that can be horizontally united in collaborative teams, in accordance to the specific requisites of each project (Friedman, 2005). Now this thinking is spreading from companies to cities, where in accordance 
with the sharing city idea, citizens are seen as a powerful source of innovation and ideas. Participatory democracy and sharing practices are sought to harness this potential.

Benkler (2006) has extensively studied the transformative potential of networked information technology especially from the viewpoint of the potential for collaboration and peer production that it offers. He further argues that the networked information technology can empower citizens, make them more aware and activate them to participate actively in societal decision-making and economic activity. Although much of his work concentrates on information technology and information platforms such software production and on-line communities like Wikileaks, it bears a strong connection to the modern collaborative economy, which can be partly seen as a results of the development Benkler has been describing.

Many argue that increasing social media and digitalization actually makes us less connected in real life and might in fact alienate us from human connections and result in isolation. Sherry Turkle (2011) for example has explored this phenomenon significantly in her book Alone Together, which offers an insightful look into the power of these new tools to dramatically change our social lives. However, in the midst of all the sacrifices and negative impacts she offers hope that the younger users are already changing course and using the tools to increase real connectivity, returning to the values of direct human connection and purpose. The sharing economy is testament to this trend as it runs counter to the isolation argument of digital technologies.

\section{Changing consumer behavior as an accelerator for sharing}

Consumer behavior is the study of the processes involved when individuals or groups evaluate, choose, purchase, use and discard products, services, experiences or ideas to satisfy their respective needs and desires (Solomon et. al. 2006). Consumer behavior is shaped by culture, affluence, personal attributes and a wide array of other factors. In addition, global megatrends, such as globalization of trade and commerce, digitalization, internet and social media and scarcity of resources have had and are having a profound impact on how consumers behave and how consumers wish to fulfil their needs. One recent megatrend is consumer engagement.

The concept of engagement has been used in various disciplines. It can be viewed as a process characterized by interactions and experiences between a subject and an object. Within marketing, engagement is taken to mean the psychological process through which customers move to become loyal towards a brand of their choice. (Bowden 2009, Brodie 2011a, Brodie 2011b). Hollebeek (2011) argues that the level of customers brand -related concentration (immersion), positive affect (passion) and the level of energy put in particular brand interactions (activation) together represent just how much the customer is prepared to exert cognitive, emotional and behavioral investments while interacting with the focal brand (Hollebeek, 2011).

Companies are inventing new ways of integrating consumers in their value creation processes to enhance the success of new products and services. At the same time consumers are creating new and novel ways of satisfying needs that often include collaboration with fellow consumers. (Blättel-Mink 2014). Research in the field of active consumership and sustainability distinguishes different types of consumer involvement, 
or active consumership: ethical consumption, prosuming of new type, user innovation or sharing economy. (Blättel-Mink 2014).

Research on consumer involvement in processes of value creation goes back to the 1980s. Alvin Toffler (1980) coined the term "prosumer"- a hybrid of producer and consumer. The term denotes consumers who are either actively involved in the creation of products and services for the market (e.g., self-service trading), or who take on some of the traditional functions of producers for their own use (e.g., do-ityourself). Toffler anticipated that the spheres of consumption and production, that have been structurally decoupled in the era of industrial society, will move closer together again in the postindustrial, respectively the service society. The so-called prosumer economy integrates consumption and production. The phenomenon of "collaborative consumption and production" implies prosumership for the benefit of a community.

Barkworth (2014) identifies six new trends that will change consumer behavior in the short- to medium term as:

\begin{tabular}{|l|l|}
\hline Multiplicity & $\begin{array}{l}\text { We are increasingly expecting things to do more that involves interacting with all our } \\
\text { senses, offers us a range of touch points to play with, and involves us entirely in new } \\
\text { experiences }\end{array}$ \\
\hline Hyper efficiency & $\begin{array}{l}\text { We are seeking and discovering ever-smarter and more efficient ways to solve age old } \\
\text { issues-such as keeping fit, lack of space and limited resources. The results are sleeker, } \\
\text { quicker and use things that have previously been ignored }\end{array}$ \\
\hline $\begin{array}{l}\text { The new } \\
\text { industrial } \\
\text { revolution }\end{array}$ & $\begin{array}{l}\text { Science is no longer a closed world, just for geeks. Digital and technological advances } \\
\text { are enabling us to create in new ways-leading to new creative forms and helping us see } \\
\text { a new appreciation of the digital as a thing of beauty. }\end{array}$ \\
\hline Escape & $\begin{array}{l}\text { In a world of austerity and grown up responsibility, we are seeing the increasing desire } \\
\text { to let go, to let loose and indulge in childlike freedom or sheer hedonistic joy. }\end{array}$ \\
\hline Mindfulness & $\begin{array}{l}\text { In a world full of buzz and surface interactions, people are seeking more depth and } \\
\text { meaning. They are craving time away from the stimulus of the internet, making their } \\
\text { leisure time more about self-development, and taking their own ethical responsibilities } \\
\text { seriously }\end{array}$ \\
\hline $\begin{array}{l}\text { Super- } \\
\text { personalized }\end{array}$ & $\begin{array}{l}\text { Personalization has been taken out of the hands and tastes of consumers. This is not } \\
\text { just bespoke you select - it is also bespoke that selects you. Advances in technology } \\
\text { mean that products are able to read consumers and give them what they want - } \\
\text { sometimes without even being asked }\end{array}$ \\
\hline
\end{tabular}

Table 1: Six trends changing consumer behavior (Barkworth 2014)

It is clear to see that all the mentioned trends are in-line with active consumer engagement, enhanced value creation and collaborative consumption or smart consumption. Companies and cities need to embrace this shift in consumer behavior and recognize that instead of traditionally managing customers or citizens, for example with some sort of CRM tool, the role of the business and the brand as well as the city is to facilitate collaborative experiences and dialogue that customers value (Baird \& Parasnis 2011). Consumers are tribal in nature and prone to influence. Cities and brands should take advantage of this opportunity that rises from consumers forming communities along mutual interests through social media.

Having an engaged customer and larger audience helps companies avoid the wastefulness of traditional media advertising. According to marketing agency Hubspot, the average banner ad has a click through rate 
of just $0.1 \%$, for Facebook being even worse at $0.04 \%$ (Zwilling 2013). Clearly engaging customers and reciprocal relationship creating value for both the consumer and the company can increase the return on any marketing efforts manifold.

Currently, the consumer context involves the increase in environmental and social consciousness, which reflects in the adoption and the preparedness to adopt alternative forms of production and consumption. This notion of change indicates that consumers are able, in the midst of a conjunction of social interactions, to take a more collective approach, where rather than consumers, they are citizens (Jackson 2007, Seyfang 2006, Spaargaren \& Oosterveer 2010). Consumers are also actively looking for countertrends to harsh competition, alienation and scarcity necessitated by the pursuit of endless economic growth. One clear trend is the transition to a more connected, ecological and sustainable way of being, consuming and collaborating (Eisenstein 2011) in which consumers are no longer maximizing self-interest but contributing to something bigger.

Heimans and Timms (2014) point out that the change in consumption habits is transforming the consumer from a passive, traditional consuming role through sharing and funding towards an active producer or coowning role where the individual has partial or complete ownership in related content or assets. They also argue that this change is reflected in new power models which are enabled by peer coordination and the agency of the crowd instead of the traditional power residing in organizations and structures (Heimans \& Timms 2014).

Not only is consumerism changing but the future of work is also open to controversy. It may no longer be the case that the majority of the workforce will be employed on full-time contracts in permanent employment. The on-demand society is demanding and paving way for an on-demand workforce. This is not only opening up new avenues for earning additional income or even creating new types of wealth but also opening up questions related to social welfare and fair and just employment conditions. (for example Ecihler 2015, O'Marah 2015, Silverstone et al. 2015).

\section{How sharing promotes sustainability}

The rise of new forms of consumption is not constrained to individual actions of buying goods to satisfy needs, but includes collaborative consumption, focusing on: products as services; redistribution markets; and collaborative life-styles (Botsman \& Rogers, 2011). Production and consumption seem to be converging where social and environmental problems are in focus. There is a strong trend demonstrating that access is being more valued than ownership, especially when it comes to commodities such as cars for example (Birdsall 2014, van den Hoff 2013, Kelly 2009). The sharing economy has the potential to provide a new pathway towards sustainability as a long-term goal (Heinrichs 2013).

The sharing economy and collaborative consumption can neither bring about sustainability by themselves. However, they may be significant elements in facilitating a new pathway towards sustainability. Collaborative systems can, in fact, be more environmentally friendly by increasing usage efficiency, reducing waste, incentivizing better products, and by absorbing the excess of production and consumption. These lead to declines in $\mathrm{CO} 2$ levels, noise and traffic congestion and natural resource savings through product life-cycle extensions and decreases in food wastage for example (Dlugosz 2014). Yannopoulou et. 
al. (2013) find references to a strong sustainability discourse and inter-personal exchange in collaborative consumption experiences such as Couchsurfing and Airbnb.

A concrete example of putting clear figures on the sustainability benefits of car-sharing is from 2012 in Sydney. In an independent economic appraisal of car sharing in the City of Sydney found that car sharing has led to an easing of parking congestion and savings to residents of $\$ 21$ million a year, including $\$ 18.5$ million in deferred car purchases by residents and business. The study found other benefits to include reduced travel times and traffic congestion, reduced parking times, personal health improvements from more walking, reduced greenhouse gas emissions due to less cars on the road and more efficient vehicle usage (SGS Economics \& Planning. 2012). Numerous other studies, and even websites such as CarPool World (https://www.carpoolworld.com/) track the saved $\mathrm{CO} 2$ emissions even in real-time.

The sharing economy makes fuller use of idle resources, allows decentralized production and consumption systems and provides an outlet for surplus or under-utilized personal goods. It has also been demonstrated to bring about social benefits through engagement, building trust and enhancing community values and cohesion for example. For a great number of people, the sharing economy provides an additional source of income, sometimes even substantial. The sharing economy brings people and their work back together through sharing, gifting, bartering, and peer-to-peer buying and selling. It thus has deep implications for how cities design urban spaces, create jobs, reduce crime, manage transportation, and provide for citizens. There are clear indications that sharing can contribute to sustainability both environmentally, socially and economically, however, it is unsure whether the scale is sufficient considering the global challenges faced today.

However, as Demailly and Novel (2014), Agyeman et al (2013) and others point out, the research on the actual, and not just the expected environmental impacts of the sharing economy have been very few and sporadic. There is no evidence demonstrating conclusively that the collaborative economy is either good or bad as a rule in terms of environmental impacts. Rather, the impact is situational and can vary from very positive to very negative. Collaborative models can for example increase the use frequency and thus shorten the lifespan of products radically, it can shift demand from rail traffic to road traffic while on the one hand it can decrease the need for ownership of products and the need for new products thus enhancing resource efficiency. Likewise shared mobility solutions can both decrease congestion (fewer cars on the road due to ride-sharing) and increase congestion (more on-demand ride providing cars from people wanting to earn extra income). In the same manner, loaning a power drill from a neighbor makes sense but renting an evening gown from someone living far away might not.

Recent studies tend to show that humans feel and react to social pain, such as loneliness and exclusion in very much the same way we react to physical pain (for example Hsu et al. 2013, MacDonald \& Leary 2005). Currently in many aging European nations loneliness is reaching epidemic proportions. It may well be that an economy built around collaboration, sharing and interaction will help to alleviate this trend and slow down the epidemic. This would have significant benefits also in terms of public costs related to health care. The latter was demonstrated by the People powered health project in the UK by NESTA, with a broader view on involving patients, their families and communities more directly in the management of long term health conditions. The project estimated savings to NHS to be at a whopping 4,4 billion GBP annually (NESTA).

There are also strong viewpoints, such as those of Share The World's Resources (2014), which believe that sharing indeed will universally result in positive outcomes and provides a solution not only to the 
environmental challenges we are facing but will also facilitate social justice, participatory democracy and the global peace movement for example. They provide a very strong argument for sharing and urge countries and cities to promote sharing activities in order to realize the full spectrum of the potential positive effects.

\section{Sharing city examples}

Cities have always been, by definition, about shared space, interaction and the exchange of goods and services. A successful city needs good governance and collective civic structures to facilitate and regulate the interface between the shared public realm and private interests, and enable effective and fair sharing of resources and opportunities (Agyeman et al 2013). Cities are natural hubs for innovation and creativity, while on the flipside they are for the most part unsustainable through issues related to pollution, waste management, social challenges and voracious consumption. Cities and urban entities are by definition very heterogeneous and thus also great laboratories for social change.

Cities are a powerful platform to promote collaborative lifestyles and the collaborative economy. In the best case scenario cities provide a platform for democratic decision making, genuine participation and creation of crowds and critical mass. Cities when truly being and working as communities might well form the very fundamentals of all future innovation systems as Kakko (2014) argues. Cities have also time and time again been criticized for their stiff, rigid and bureaucratic decision making structures and their resistance to change, innovation and new ways of organizing economic activity and civic engagement and activism. In our benchmarking research into sharing cities we have identified three distinct approaches to the collaborative economy that cities are embracing.

\begin{tabular}{|c|c|c|c|}
\hline & $\begin{array}{l}\text { The city as the primus } \\
\text { motor }\end{array}$ & $\begin{array}{l}\text { The city as the } \\
\text { facilitator or active } \\
\text { reacting party }\end{array}$ & $\begin{array}{l}\text { The city as the break } \\
\text { pedal }\end{array}$ \\
\hline One sentence & $\begin{array}{l}\text { The collaborative } \\
\text { economy thrives } \\
\text { BECAUSE of the city }\end{array}$ & $\begin{array}{l}\text { The collaborative } \\
\text { economy thrives WITH } \\
\text { the city }\end{array}$ & $\begin{array}{l}\text { The collaborative } \\
\text { economy thrives } \\
\text { DESPITE the city }\end{array}$ \\
\hline $\begin{array}{l}\text { The city relative to the } \\
\text { collaborative economy }\end{array}$ & $\begin{array}{l}\text { The city is the prime } \\
\text { driver behind the } \\
\text { proliferation of the } \\
\text { collaborative economy; } \\
\text { it is the main engine } \\
\text { driving the success of } \\
\text { the collaborative model }\end{array}$ & $\begin{array}{l}\text { The city is reacting } \\
\text { positively to } \\
\text { collaborative initiatives } \\
\text { that have started at the } \\
\text { grassroots and citizens } \\
\text { level; the city turns } \\
\text { itself into an active } \\
\text { facilitator removing } \\
\text { potential barriers and } \\
\text { enabling growth. }\end{array}$ & $\begin{array}{l}\text { The city is not } \\
\text { embracing the } \\
\text { collaborative models } \\
\text { but they thrive despite } \\
\text { the city's actions; in } \\
\text { some senses the city } \\
\text { acts as a brake pedal }\end{array}$ \\
\hline $\begin{array}{l}\text { Key background } \\
\text { elements }\end{array}$ & $\begin{array}{l}\text { Sustainability concerns, } \\
\text { especially } \\
\text { environmental and } \\
\text { social challenges }\end{array}$ & $\begin{array}{l}\text { Dire housing market, } \\
\text { thriving start-up and } \\
\text { innovation scene, } \\
\text { rapidly growing city }\end{array}$ & $\begin{array}{l}\text { Practical orientation, } \\
\text { wariness towards public } \\
\text { authorities and anything } \\
\text { authoritarian }\end{array}$ \\
\hline Key characteristics & $\begin{array}{l}\text { Enthusiastic mayor/ } \\
\text { other city officials, city }\end{array}$ & $\begin{array}{l}\text { Plenty of start-ups } \\
\text { operating in the }\end{array}$ & $\begin{array}{l}\text { Collaborative models } \\
\text { are in a sense part of }\end{array}$ \\
\hline
\end{tabular}




\begin{tabular}{|l|l|l|l|}
\hline & $\begin{array}{l}\text { ordinances changed to } \\
\text { accommodate } \\
\text { collaborative models; } \\
\text { city initiates and } \\
\text { organizes information } \\
\text { sharing }\end{array}$ & $\begin{array}{l}\text { collaborative space; } \\
\text { thriving economic force. }\end{array}$ & $\begin{array}{l}\text { the alternative or } \\
\text { underground } \\
\text { movement; plenty of } \\
\text { start-ups or small co- } \\
\text { ops operating in the } \\
\text { space }\end{array}$ \\
\hline $\begin{array}{l}\text { Key collaborative } \\
\text { actions }\end{array}$ & $\begin{array}{l}\text { Usage of public space, } \\
\text { mobility, housing }\end{array}$ & Mobility, housing & Food, work, services \\
\hline
\end{tabular}

Table 2: Three identified types of sharing cities and their differences.

In the first category are cities that act as the prime driver of collaborative lifestyles. In these cities, such as the successful sharing city of Seoul, the city has taken an extremely visible and strong role in driving the collaborative economy. This has often started with a very deliberate and conscious development effort with a few prominent and powerful governance officials. Characteristically the adoption of the collaborative economy is motivated by large-scale social and environmental challenges that relate to resource efficiency and social inclusivity. Collaborative solutions are seen as creating solutions to city pollution, congestion, as well as challenges related to social development, such as social exclusion of youth and old generations as well as the fragmentation of social relationships and networks. In these examples, the cities draw up new ordinances promoting sharing behavior, they actively disseminate information and attempt to get citizens involved and also participate by for example extending the use of city spaces for all citizens through different platforms.

In the second category are cities that positively react to the organic growth of the collaborative economy. In these cities, such as many cities in the US like San Francisco, there is a thriving start-up scene that has grown organically from the needs and demands presented in the communities and that have been solved by the participants in those communities. The cities have then actively deregulated and disassembled unnecessary structures that prohibited the growth of the collaborative economy. Characteristically the cities view the collaborative economy positively and are ready to embrace the benefits that it is assumed to bring about.

The third category includes cities where the collaborative economy thrives despite city actions that often work against its success. In these cities, the collaborative scene is very active, but seems to be more part of the alternative or underground movement. One example is Berlin, where in the near-history collaborative lifestyles partly meant a disruption of social structures through squat houses for example. In these cities, governance is wary of the collaborative economy perhaps for a fear of those lifestyles and models disrupting social equality and coherence. In these cities, the collaborative economy thrives despite of the city's more reluctant attitude towards active advancement of the phenomena.

The approaches presented above are all different and suit different cities, different cultural backdrops and differing stages in the adoption of the collaborative economy. One approach is not better than another and any city can essentially become a sharing city by moving along any of these approaches, depending on the inherent characteristic of the city and its citizens. Most cities and their approaches fall somewhere between the presented three. Through our workshop work in Finland we have come across the shared feeling that engaged citizens feel that the sharing practices need to develop from the ground up, the city should only act as a facilitator and have the role of an active enabler through scrapping hindering regulative practices. Indeed, good and well planned regulation can be a powerful tool for creativity and innovation; and thus 
cities should pay special attention to designing the regulatory framework to be supportive of sharing practices where they have the potential to bring about positive environmental and social impacts; and in abolishing such regulation which hinders them. The drafting of new regulation would ideally happen in a transparent and participatory process with a clear link to the decision making.

\section{How can sharing cities promote sustainability}

A reinvention and revival of sharing in cities could enhance equity, rebuild community and significantly cut resource use. With modern technologies the intersection of urban space and cyber-space provides an unsurpassed platform for a more inclusive and environmentally efficient sharing economy (Agyeman et al 2013).

The most live and pressing sharing economy issue for many cities is the approach it takes to regulation (Goulden 2015, Wosskow 2014). Since there is no definitive answer on the sustainability impacts of the sharing or the collaborative economy the role of policy makers becomes that of an enabler and advocate. It is in fact up to the cities now to promote smarter regulation that ensures that the ways in which the collaborative models are deployed are such that promote positive environmental impacts (Demailly \& Novel 2014, Frenken et al 2015, Wosskow 2014). AirBnB for example has become regulated in some cities so as to promote a true sharing economy but to inhibit the negative side-effects. The Amsterdam municipality for example limits the number of days people can rent out their apartment through AirBnb to ensure that it is only occasional and not a permanent and unregulated hotel (Coldwell 2014). This ensures that the benefits are realized as expected but that the downside and unintended negative consequences do not realize themselves, as they have in other cities with stressed housing markets, such as New York or Brooklyn.

Demailly and Novel (2014) suggest that public authorities should engage in research of identifying the most virtuous models and then implement support measures to ensure those models are proliferated on a large scale. There are well grounded arguments, such as those proposed by Sundararajan (2014) and Cohen and Sundararajan (2015) that the collaborative economy should be allowed to self-regulate and more regulatory responsibility should be delegated to them leaving government oversight only for certain aspects. However, self-regulation is not the same as deregulation or no regulation but an effective regulatory mechanism with the reallocation of regulating authority and power elsewhere than with the government. Currently, as Goulden (2015) points out, there is a growing and wide range of policy initiatives and experiments globally.

One of the key roles for the city officials is to enable collaborative lifestyles and make their inclusion or a transition towards them easier. In our review of existing models and our own workshop results we have found some key issues that need the authorities' attention. The most pressing concerns relate to making taxation easier, encouraging collaborative models through government/ city procurement, helping to find solutions for insurance questions related to shared use of assets and opening up public spaces and potentially other assets more generously for public use. Taxation rules and platforms for registering sporadic taxable income need to be digital and easy-to-use for everyone involved. Preferably they could be combined with the collaborative platforms themselves automatically. This would also decrease resistance from legacy operators, especially those in the transport and hospitality sectors, towards the collaborative economy. 
Government and city procurement represents a substantial economic force. Cities need to ensure that collaborative models are as preferable as any other and that they can easily be chosen as an option for example when traveling or organizing events. City assets such as buildings, parks and other assets like car fleets also need to listed and an exploration made into whether they could be opened further for public use when not in official use as they are also idle a lot of the time. For example in Finland, most public school spaces are open for sports and music clubs and schools in the evening hours when they would otherwise be empty. This increases their use efficiency, reduces the stress and need on other sports or music facilities and decreases the costs related to hobbies thus enabling more families the opportunity to have their kids have a hobby.

Surplus food and edibles are a major concern in an economic, environmental and a social sustainability perspective. Cities can play a major part in redistributing surplus food from stores, schools and other public places (such as hospitals for example). As an example, a new surplus food redistribution center was opened recently in Vantaa, Finland as a joint effort between the city and the local church. The center redistributes roughly $7.000 \mathrm{~kg}$ of food weekly to families in need. More such centers are needed as the estimated annual food wastage in the area is roughly 25 million tons.

On a practical level, cities can start a sector-based review of the alternatives for promoting sharing. For example in terms of accommodation, cities need to review the existing regulation and the potential hindrances it sets on shared space. Regulations need to be crafted in proportion to the scale of space sharing and the logic behind potentially stringent regulations on sub-letting need to be revisited. Cities also need to review existing parking regulations, as at least in Finland, the city master and building plans restrict parking to an extent perhaps no longer relevant. These actions require only paperwork and thus entail only the cost of labor without any changes necessary to the spaces themselves, they are the very low-hanging fruits.

Public authorities also need to be taking a systems view on the development of mobility and where possible and sensible encouraging and incentivizing the shift from a car-based mobility system towards a public transport based mobility system. The city of Helsinki in Finland has started a mobility as a service project that aims to build a system combining different modes and models of transport into a seamless service. A trip may include car-pooling, taxis, city-bikes, trams, private car, etc. with smooth transitions and payments. This will offer the customer a wide choice of alternatives for completing any one journey and also a choice in the level of comfort and convenience as well as costs. The new mobility as a service concept combines mass- transportation, demand-based traffic and private vehicles in one transport ecosystem offering plenty of freedom for choice.

On an easier level to start, cities should look into the potential and availability of preferential parking spaces offered for shared transport operators as well as the usage of bus lanes in highly congested areas. Special care needs to be paid especially to the design of new mass transport hubs to ensure that shared transportation and bikes for example are an easy option; i.e. they have enough designated space in the vicinity of such hubs. All these minor changes would make collaborative models more attractive and lower the threshold to take part in these systems.

The benefits and challenges related to the sharing city are different on a public or societal and on a private or individual level. On the private level the first reasons to try out the collaborative economy often relate to price and convenience (Campbell-Mithun 2012). Subsequently the benefits often relate to flexibility, belonging to a group, wanting to be part of a movement, getting to know new cultures, doing something 
positive from a sustainability perspective or enriching the social life for example. On the public or societal level the sought benefits often relate to making resource use more efficient, moving towards a circular economy through eliminating waste, increasing communality, creating jobs, employment and subsequently tax revenue, fostering innovations and improving the reputation and attractiveness of the city. Arguably cities have a huge role to play in advancing sustainable solutions, also those from the collaborative economy, though their role in purchasing as pointed out also by Goulden (2015).

\section{Conclusion and outlook}

The sharing economy seems to bring about substantial benefits socially, environmentally and also economically. Undoubtedly it also raises many questions, which relate to public policy, urban planning, fairness and safety for example. Currently the information on whether collaborative models can bring about sustainability is inconclusive. However, it would seem that the Sharing City concept offers both a sustainable foundation for participatory urban democracy and a transformative approach to city futures. A sharing culture potentially also offers the potential to build greater empathy and solidarity leading to beneficial social impacts to be realized over time leading to a fairer, more inclusive and more just society over time. It may well be that the positive effects of sharing cities relate more to the social and economic rather than the environmental tenet of sustainability.

There are different ways in which cities can approach the sharing economy and we have explored some in this paper. All cities thus far that have adopted the sharing city model have seen positive effects, although all being in the early stages of concept adoption and development. We believe that fostering the growth of the sharing economy is worthwhile and something that merits further studies to see whether it can be used to boost prosperity and resilience in times of economic crisis and climate change. Cities could act as a platform for sharing and provide breeding ground for reaping the benefits of the collaborative economy. It needs to be further studied how cities could contribute to more resilient ways of providing housing, transportation, goods, food and jobs through promoting collaborative business models.

While it may not be clear whether the adoption of collaborative business models and the sharing economy in city planning will result in sustainability, it is clear that sustainability can not be achieved without the involvement of cities and their residents. If, and as evidence points, the collaborative economy can enhance participation, involvement and engagements, it just might be what is urgently needed. 


\section{References:}

Agyeman, J., McLaren D., Schaefer-Borrego A. 2013. Sharing Cities. Briefing for Friends of the Earth.

Ali, R. 2015. Airbnb's Revenues Will Cross Half Billion Mark in 2015, Analysts Estimate.

http://skift.com/2015/03/25/airbnbs-revenues-will-cross-half-billion-mark-in-2015-analysts-estimate/

Baird, H.C., Parasnis, G. 2011. From social media to social customer relationship management. Strategy \& Leadership Journal. Vol 39. No 5. pp. 30-37

Barkworth, H. 2014. Six Trends That Will Shape Consumer Behavior This Year. Forbes Magazine. http://www.forbes.com/sites/onmarketing/2014/02/04/six-trends-that-will-shape-consumer-behaviorthis-year/

Belk, R. (2007) Why Not Share Rather Than Own? The ANNALS of the American Academy of Political and Social Science May 2007 vol. 611 no. 1 126-140

Benkler, Y. 2006. The Wealth of Networks. How social production transforms markets and freedom. Yale University Press.

Berthon, P., Pitt, L., and Campbell, C. (2008). Ad Lib: When consumers create the ad. California Management Review, 50(4), 6-30.

Birdsall, M. (2014). Carsharing in a Sharing Economy. Institute of Transportation Engineers. ITE Journal. Apr 2014;84, 4. pg. 37-40.

Blättel-Mink, B. 2014. Active consumership as a driver towards sustainability? GAIA 23/S1(2014): 158 -165.

Botsman, R. \& Rogers, R. 2010. What's mine is yours: the rise of collaborative consumption. New York, USA. HarperCollins.

Botsman, R. 2014. Sharing's not just for start-ups. Harvard Business Review. September 2014. pp. 23-25.

Botsman, R. 2013. The Sharing Economy Lacks A Shared Definition. FastCo Exist Blog.

http://www.fastcoexist.com/3022028/the-sharing-economy-lacks-a-shared-definition

Bowden, J. L.- H. (2009). The Process of Customer Engagement: a Conceptual Framework. Journal of Marketing Theory \& Practice, 17 (1), 63-74.

Brodie, R. J., Hollebeek, L. D., Jurić, B., \& Ilić, A. (2011a). Customer Engagement. Journal of Service Research, 14 (3), 252- 271.

Brodie, R. J., llic, A., Juric, B., \& Hollebeek, L. (2011b). Consumer engagement in a virtual brand community: An exploratory analysis. Journal of Business Research (0).

Campbell-Mithun 2012. National study quantifies reality of the "Sharing economy" movement. http://www.campbell-mithun.com/678 national-study-quantifies-reality-of-the-sharing-economymovement 
Cohen, M. and Sundararajan A. 2015. Self-Regulation and Innovation in the Peer-to-Peer Sharing Economy. The University of Chicago Law Review. 82 U Chi L Rev Dialogue pp.116-133.

https://lawreview.uchicago.edu/page/self-regulation-and-innovation-peer-peer-sharing-economy

Coldwell, W. 2014. Airbnb's legal troubes: what are the issues? The Guardian. $8^{\text {th }}$ July 2014. http://www.theguardian.com/travel/2014/jul/08/airbnb-legal-troubles-what-are-the-issues

Contreras, J. 2011. MIT Sloan grad on the "sharing economy," the next big trend in social commerce. http://mitsloanexperts.mit.edu/mit-sloan-grad-on-the-sharing-economy-the-next-big-trend-in-socialcommerce/

Da Silva, M. E.; Figueiró, P. Schmitt J., Marcio L. M.; Nascimento, L. F. 2014. Trends And Alternatives For Production And Consumption Towards To A New System's Dynamic. Independent Journal Of Management \& Production (IJM\&P), V. 5, N. 1, October-January 2014.

Demailly, D., Novel, A.-S. (2014). The sharing economy: make it sustainable, Studies N03/14, IDDRI, Paris, France, $30 \mathrm{p}$.

Dervojeda K., Verzijl D., Nagtegaal F., Lengton M., Rouwmaat E., Monfardini E. \& Frideres L. 2013. The Sharing Economy. Accessibility Based Business Models for Peer-to-Peer Markets. European Commission. Enterprise and Industry. Case Study No. 12.

http://ec.europa.eu/enterprise/policies/innovation/policy/business-innovation-observatory/files/casestudies/12-she-accessibility-based-business-models-for-peer-to-peer-markets_en.pdf

Dlugosz, P. M. 2014. The Rise of the Sharing City. Examining origins and futures of urban sharing. IIIEE Publications. Lund. Sweden.

Eckhardt, G. M. \& Bardhi F. 2015. The Sharing Economy Isn't About Sharing at All. Harvard Business Review. Jan 28, 2015. https://hbr.org/2015/01/the-sharing-economy-isnt-about-sharing-at-all

Eichler L. 2015. The brave new world of "on-demand work. The Globe and Mail. $24^{\text {th }}$ April 2015.

http://www.theglobeandmail.com/report-on-business/careers/career-advice/life-at-work/the-brave-newworld-of-on-demand-work/article24066880/

Eisenstein C. 2011. Sacred Economics. Money, Gift \& Society in the Age of Transition. Evolver Editions.

Forbes. 23.01.2013. Airbnb And The Unstoppable Rise Of The Share Economy.

http://www.forbes.com/sites/tomiogeron/2013/01/23/airbnb-and-the-unstoppable-rise-of-the-shareeconomy/

Foster, J. B.; Magdoff, F. (2011) The great financial crisis - three years on. Monthly Review. Available: http://monthlyreview.org/2010/10/01/the-great-financial-crisis-three-years-on

Fottler, M. D. (1981). Is management really generic? Academy of Management Review, 6(1), 1-12.

Frenken, K., Meelen, T., Arets, M. and van de Glind P. 2015. Smarter regulation for the sharing economy. The Guardian. 20th May 2015. http://www.theguardian.com/science/politicalscience/2015/may/20/smarter-regulation-for-the-sharing-economy

Friedman, T. L. (2005). The World is Flat: A Brief History of the Twenty-First Century. Farrar, Straus \& Giroux 
Goulden, H. 2015. 8 Steps towards a sharing city... Nesta. http://www.nesta.org.uk/blog/8-steps-towardsharing-city

Grassl, W. 2011. Hybrid Forms of Business: The Logic of Gift in the Commercial World. Journal of Business Ethics, Supplement100 (Mar 2011): 109-123.

Heimans J. \& Timms H. 2014. Understanding "New Power". Harvard Business Review. December 2014. pp.48-56.

Heinrichs, H. , \& Grunenberg, H. (2013). Sharing Economy: Towards a New Culture of Consumption?. 21 S. Lüneburg: Centre for Sustainability Management.

Heinrichs, H. 2013. Sharing Economy: A Potential New Pathway to Sustainability. GAIA 22/4 (2013): 228231.

Hollebeek, L. (2011). Exploring customer brand engagement: definition and themes. Journal of Strategic Marketing, 19(7), 555-573

Hsu D T, Sanford, B J, Meyers K K, Love T M, Hazlett K E, Wang H, Ni L, Walker S J, Mickey B J, Korycinski S T, Koeppe R A, Crocker J K, Langenecker S A and Zubieta J-K. 2013. Response of the $\mu$-opioid system to social rejection and acceptance. Molecular Psychiatry 18, 1211-1217 (November 2013).

Jackson, T. (2007) Sustainable Consumption. In: Atkinson, G.; Dietz, S.; Neumayer, E. (Ed.). Handbook of Sustainable Development. Edward Elgar Publishing.

Kakko, I. 2014. Oasis Way and the Post-Normal Era - How Understanding Serendipity Will Lead You to Success. St. Petersburg. 96p. Available at http://www.slideshare.net/ilkkakakko/new-book-ilkka-kakkooasis-way-and-the-postnormal-era-how-understanding-serendipity-will-lead-you-to-success

Kell, J. 2013. Avis to Buy Car-Sharing Service Zipcar. The Wall Street Journal. Jan 2., 2013. http://www.wsj.com/articles/SB10001424127887324374004578217121433322386

Kelly, K. 2009. Better than Owning. January 2009. The Technium.

http://kk.org/thetechnium/2009/01/better-than-own/

Kozinets, R. V.; Hemetsberger, A.; Schau, H. J. (2008) The Wisdom of Consumer Crowds: Collective Innovation in the Age of Networked Marketing, Journal of Macromarketing, v. 28, n. 4, p. 339-354

MacDonald G. \& Leary, M. R. 2005. Why Does Social Exclusion Hurt? The Relationship Between Social and Physical Pain. Psychological Bulletin. 2005. Vol. 131. No. 2. pp. 202-223

Mattioli, D. \& Boston, W. 2014. Daimler Expands Into Ride Sharing. The Wall Street Journal. Sept.3,2014. http://www.wsj.com/articles/daimler-moves-into-ride-sharing-economy-1409750844

NESTA. People-powered health project website. http://www.nesta.org.uk/project/people-powered-health. Accessed 15.6.2015

O'Marah, K. 2015. Five Disruptive Technologies that Will Create Jobs. TIME magazine. May $29^{\text {th }} 2015$. http://www.forbes.com/sites/kevinomarah/2015/05/29/five-disruptive-technologies-that-will-createjobs/?ss=future-work 
Onaran, Ö. (2010) The crisis of capitalism in Europe, West and East. Monthly Review. Available: http://monthlyreview.org/author/ozlemonaran

Owyang, J. 2014. Collaborative economy honeycomb. Creative commons.

Owyang, J., Samuel, A. \& Grenville, A. 2014. Sharing is the New Buying. http://www.webstrategist.com/blog/2014/03/03/report-sharing-is-the-new-buying-winning-in-the-collaborative-economy/

Porter, M. E. \& Kramer, M. R. 2011: "Creating Shared Value. How to reinvent capitalism—and unleash a wave of innovation and growth." Harvard Business Review, 1-2/89, 62-77

PWC. 2014. Five key sharing economy sectors could generate $£ 9$ billion of UK revenues by 2025. http://pwc.blogs.com/press room/2014/08/five-key-sharing-economy-sectors-could-generate-9-billion-ofuk-revenues-by-2025.html

Rifkin, J. 2014. The Zero Marginal Cost Society: The Internet of Things, the Collaborative Commons, and the Eclipse of Capitalism. Palgrave Macmillan.

Riley, T. 2014. Sharing economies are here to stay. The Guardian.

http://www.theguardian.com/sustainable-business/behavioural-insights/sharing-economy-sustainablealternative-economics

Sempels C. \& Hoffman J.. 2013. Sustainable Innovation Strategy. Creating value in a world of finite resources. Palgrave Macmillan.

Seyfang, G. (2006) Ecological citizenship and sustainable consumption: examining local organic food networks, Journal of Rural Studies, v. 22, n. 4, p. 383-395.

SGS Economics \& Planning. 2012. Benefit-Cost Analysis of Car Share within the City of Sydney. Final Report. http://www.cityofsydney.nsw.gov.au/ data/assets/pdf file/0012/122502/CarShareEconomicAppraisalFIN ALREPORT.pdf

Share The World's Resources. 2014. Sharing as our common cause. www.sharing.org/common-cause

Silverstone Y., Tambe H. and Cantrell S. M. 2015. The Rise of the extended Workforce. Accenture. www.accenture.com/SiteCollectionDocuments/PDF/Accenture-Future-of-HR-Rise-Extended-Workforce.pdf

Solomon, R. M., Bamossy, J.,G., Askegaard, T., Hogg, K. 2006. Consumer behavior: A European perspective. 3rd ed. Prectice-Hall

Spaargaren, G.; Oosterveer, P. (2010) Citizen-Consumers as Agents of Change in Globalizing Modernity: The Case of Sustainable Consumption, Sustainability, v. 2, n.7, p. 1887-1908

Sundararajan, A. 2014. Trusting the 'Sharing Economy' to Regulate Itself. March 3, 2014. The New York Times. http://economix.blogs.nytimes.com/2014/03/03/trusting-the-sharing-economy-to-regulateitself/?smid=tw-share\&_r $r=1$

Toffler, A. 1980. The third wave. New York: Morrow.

Turkle S. 2011. Alone Together. Basic Books. 
Wall Street Journal. 21.3.2014. Airbnb Is in Advanced Talks to Raise Funds at a \$10 Billion Valuation. http://online.wsj.com/news/articles/SB10001424052702303802104579451022670668410

van den Hoff, R. 2013. Mastering the Global Transition on Our Way to Society 3.0. Society 3.0 Foundation.

Vandepitte, M. (2011) Crisis del capitalismo. Rebelión. Available:

http://www.rebelion.org/noticia.php?id=121086

Weber, H. 2014. Airbnb rumored to raise $\$ 500 M$ in new round led by TPG Capital.

http://venturebeat.com/2014/03/20/airbnb-rumored-to-raise-500m-in-new-round-led-by-tgp-capital/

Wosskow, D. 2014. Unlocking the sharing economy. An independent review.

https://www.gov.uk/government/uploads/system/uploads/attachment data/file/378291/bis-14-1227-

unlocking-the-sharing-economy-an-independent-review.pdf

Yannopoulou, N., Moufahim, M., Bian, X. 2013. User-Generated Brands and Social Media: Couchsurfing and AirBnb. Contemporary Management Research, Pages 85-90, Vol. 9, No. 1, March 2013

Zwilling, M. 2013. The Old Ways Of Social Media Marketing Are Broken. Forbes Magazine.

http://www.forbes.com/sites/martinzwilling/2013/11/29/the-old-ways-of-social-media-marketing-arebroken/ 